\title{
110 下咽頭・頸部食道癌の頸転移と治療成績の相関
}

\author{
村上泰 - 原口茂德 - 岡田康司
}

(慶応義塾大学医学部耳鼻咽喉科)

過去 6 年間の間に手術した 63 症例の下咽頭頸部 食道癌について、特に頸転移と予後との相関につ いてのべ、頸部リンパ節処理についての臨床的問 題点をあげて私見を述べた。症例の内訳は No 23、 $\mathrm{N} 132 、 \mathrm{~N}_{2} 5 、 \mathrm{~N}_{3} 3 、 て ゙ あ っ て 、$ 生存例についてま とめると、No 21 例 ( $91 \%$ )、N1 17 例 ( $53 \%$ )、 N2 1 例 $(20 \%) \mathrm{N} 3$ ゼロ ( $0 \%)$ 、合計39例が 生存している。 $\mathrm{N} 1 \sim \mathrm{N} 3$ についてまとめてみると 45\%の生存率でNQこくらべて著しく低率である。 $\mathrm{N}$ 進行例は Tでも進行例であるから、頸転移との 相関だけで予後を比較すべきではないが、つよい 関係を持っていることは確実で、頸部リンパ節を いかに処理すべきかがやはり重要なポイントとな る。そこで

1. Noに対する予防的廓清は必要か

2. $\mathrm{N} 1$ に対する反対側予防的廊清は必要か

3. 術中用指触知法で廓清の適応をきめられるか

4. post-cricoid や後壁中央型では、どこをど こまで廓清すべきか

5. N円例の廓清手術はどこまでやるべきか

6. paratracheal nodes の廓清で反回神経を保 存できるか
の 6 点について我々の経験を中心にして私見を 述べ 今後慎重に検討すべき問題点として提出し た。

質問 海野 (旭川医大耳)

FAR 療法で $3000 \mathrm{rads}$ かけていられるとのこ とであるが、Nに対してどの位の効果があると考 えられるか。

回答村上 (慶応大耳)

(1) 各個症例で術前治療を選択していない、全例 同様にFAR 3000 r です。

[ 重松先生への回答]

すでに照射単独の時代ではないはずですから、 化学療法との併用時の照射量について検討して下 さい。 